\title{
Determinants of Commercial Bank Profitability in Sub-Saharan Africa
}

\author{
Munyambonera Ezra Francis ${ }^{1}$ \\ ${ }^{1} \mathrm{PhD}$, Economic Policy Research Centre (EPRC), Kampala, Uganda \\ Correspondence: Munyambonera Ezra Francis, Economic Policy Research Centre (EPRC), Kampala, Uganda. \\ E-mail: emunyambonera@eprc.or.ug
}

Received: June 11, 2013

doi:10.5539/ijef.v5n9p134

\author{
Accepted: June 10, 2013 \\ Online Published: August 26, 2013 \\ URL: http://dx.doi.org/10.5539/ijef.v5n9p134
}

\begin{abstract}
The central theme of this study was to investigate the determinants of commercial bank profitability in Sub-Saharan Africa. The analysis used an unbalanced panel of 216 commercial banks drawn from 42 countries in SSA for the period 1999 to 2006.

Using the cost efficiency model, bank profitability was estimated using panel random effects method in static framework. The explanatory variables are growth in bank assets, growth in bank deposits, capital adequacy, operational efficiency (inefficiency), and liquidity ratio as well as the macroeconomic variables of growth in GDP and inflation. The findings clearly show that both bank-specific as well as macroeconomic factors explain the variation in commercial bank profitability over the study period.

These findings demonstrate the importance of both bank level as well as macroeconomic factors in explaining commercial bank profitability in Sub-Saharan Africa. The policy implications drawn from this paper are that if banks are to attain profitability improvements, both bank level as well as macroeconomic factors are important.
\end{abstract}

Keywords: commercial bank, cost efficiency, profitability

\section{Introduction}

\subsection{Background and Motivation}

Despite extensive reforms in the financial sector in Sub Saharan Africa during 1980s and 1990s, with a view of improving access to financial services to private agencies, financial depth in the sub-region has remained very low and not improving over the years. Commercial bank performance has been poor characterized by low levels of private credit, high interest rate spreads, high levels of non-performing loans, poor asset quality, operational inefficiencies, among others (Panayiotis, et al., 2005).

The low financial depth of commercial banks would suggest investment and economic growth is still heavily dependent on foreign savings in form of external finance. The World Bank (2006) acknowledged that there are few signs of sustainable progress arising from financial sector and public enterprise reform. The report called for more wide reforms in the financial sector to achieve higher efficiency in the banking sector. It is the growth and efficiency of commercial banks in many countries that would be important to finance the desired economic growth in the different segments of the economy.

With extensive information gap on commercial banking in SSA, This paper therefore examines the determinants of commercial bank profitability in Sub-Saharan Africa, considering the effect of the variables related to bank size, capital adequacy, liquidity risk, asset quality, credit risk, operational efficiency as on the prevailing economic environment. The study is in response to what has been previously been proposed by different scholars that there is need for more research and information on African commercial banks to inform policy decisions for the sector improvements.

\subsection{Objectives of the Study}

The main objective of the study is to investigate the determinants of commercial banks' profitability in SSA over the period 1999 to 2006. The research draws policy implications for industry improvement in the sub-region. The analysis utilises both bank level as well as macroeconomic factors to measure profitability performance over the years. 


\subsection{Significance of the Study}

Empirical evidence clearly shows that studies focusing on Sub-Saharan Africa's commercial banking sector are still scanty and limited. Even the few studies which have been undertaken point to a need for further investigation of the factors that have continued to cause poor performance of commercial banks in the sub-region, notwithstanding the reforms in the last two decades. Most of the evidence in regard to commercial bank performance is largely focused on the developed economies environments and the conclusions may not be useful for African commercial banking improvements. Much of the empirical work on developed countries and a few on Africa and other developing countries on financial systems' performance, have suggested a need to undertake further research on SSA banking system using sufficient data and robust methods to be able provide sufficient information for effective policy implementation of commercial banking. It is also apparent that the a few studies on SSA commercial banking are more of country specific and don't provide comparative information across countries. It is against this back ground that research was undertaken and its significance is that;

It contributes to the frontier of knowledge on SSA commercial banking using larger scope of commercial banks drawn from 42 SSA countries. A few studies on SSA have used data only drawn from single country studies or smaller sub-regions like West Africa, North Africa and Middle East and East Africa. The conclusions from these studies may not be objectively relied on to inform policy on the entire SSA banking system.

It uses robust econometric panel methods, using elaborate panel data of 216 commercial banks of drawn from 42 SSA countries to explain bank profitability. A few studies on Africa commercial banking have applied simple econometric tools to measure performance. These tools however may be lacking in explaining the variability in performance within and across banks which this paper addresses.

\subsection{Organization of the Paper}

The paper is organized as follows. Chapter section 1.0 presents the background and study motivation. In section II, the literature review on bank performance is explained. The conceptual framework and methodology are discussed in chapter III. In sections IV and V, the regressions results on bank profitability are explained. Lastly, the conclusions and implications drawn from the study findings are given in chapter VI.

\section{Literature Review}

\subsection{Determinants of Bank Profitability}

The available empirical evidence tend to show that studies on banking have extensively been concentrated more on developed and a few developing countries and limitedly on SSA. There is thus insufficient information on the determinants of bank performance in SSA that would require further investigation (Short, 1979; Bourke, 1989; Molyneux and Thornton, 1992; Demerguc-Kunt and Huizinga, 2001). The study in this in direction would therefore be important. Studies on bank performance have focused on bank specific, industry specific and macroeconomic factors to explain bank performance (Nissanke and Aryeetey, 2006). While the results on bank specific and macroeconomic factors are explicit and point to one directional effect to bank performance, the results on the impact of industry specific factors are mix and in most cases insignificant to explain the behavior of banks. The sections that follow discuss the key factors of bank profitability performance.

\subsection{Bank-Specific Determinants}

In trying to understand commercial bank performance in global context, studies on profitability have largely used returns on average bank assets (ROAA), net interest margin (NIM) and return on average equity (ROAE), as common measures. As such traditionally, the impact on bank performance has been measured by bank-specific factors such as capital adequacy, credit risk, liquidity risk, market power and regulatory costs. More recently, research has also attempted to focus on the impact of macroeconomic factors on banks' performance.

Mercia, et al. (2002), Toddard, et al. (2004), and Panayiotis et al. (2005) showed that bank profitability is a function of internal and external factors. Internal factors include bank-specific; while external factors include both industry-specific and macroeconomic factors. According to this literature, there are six standard key bank-specific indicators that are widely used to study banks. These include profitability, capital adequacy, asset quality, operational efficiency, and growth in bank assets. Industry-specific factors include ownership, bank concentration index; while macroeconomic factors include interest rate, interest rate spread, inflation and levels of economic growth represented either GDP or GDP per-capita. Most of these factors are included in this study to estimate bank profitability for SSA banks.

Al-Hashimi (2007) investigated the determinants of bank net interest margin in 10 SSA countries, and applied an 
accounting decomposition model as well as panel regressions. The study indicated that credit risk and operational inefficiencies explain most of the variation in net interest margins across the region, with macroeconomic factors, having less influence on performance

There is also an extensive literature based on the idea that an expense-related variable should be included in a profit function. For example, Bourke (1989) and Molyneux and Thornton (1992) found a positive relationship between better-quality management and profitability. Anthanasoglou, et al. (2006) study on the South Eastern European banking industry over the period 1998 to 2002, proposed new approaches in understanding bank profitability.

\subsection{Industry-Specific Determinants}

Another strand of literature emphasizes the importance of market structure and bank specific variables in explaining performance heterogeneities across banks. This literature is based on the structure-conduct-performance (SCP) paradigm and is also applicable to contestable markets, firm-level efficiency, and the roles of ownership and governance in explaining bank performance (Berger, 1995; Berger and Humphrey, 1997; Bikker and Hu, 2002; Goddard et al., 2004).

Extensive empirical evidence does not provide conclusive proof that bank performance is influenced either by concentrated market structures and collusive price setting behavior or superior management and production techniques. Bank efficiency levels vary widely across banking sectors (Altunbaş et al., 2007; Schure et al., 2004). While some studies have questioned the relationship between bank ownership status and market power to profitability or not, there is contrasting evidence on the role of market power on bank performance (Short, 1979), Bourke (1989) and Molyneux and Thornton (1992) and Eichengreen and Gibson (2001).

\subsection{Macroeconomic Determinants}

The last group of profitability determinants deals with macroeconomic control variables. The common variables include inflation rate, the long-term interest rate and rate of economic growth (Panayiotis et al., 2005). More recently, a number of studies emphasize the relationship between macroeconomic variables and bank risk. Allen and Saunders (2004) provided evidence of the importance of macroeconomic factors in determining the profitability of banks in the sampled.

Saunders and Schumacher (2000) applied a model of Ho and Saunders (1981) to study the determinants of interest margin in six European Union and US banks during the period 1988 to 1995. They established that macroeconomic volatility and regulations have a significant impact on bank interest margin. The result pointed out an important trade-off between ensuring bank solvency, as defined by high capital to asset ratio, and lowering cost of financial services to consumers, as measured by lower interest rate margin.

Bourke (1989), Molyneux and Thornton (1992), Demerguc-Kunt and Huizinga (1999) and Bikker and Hu (2002) identified possible cyclical movements in bank profitability. Bikker and $\mathrm{Hu}$ (2002) established that bank profits are positively correlated with movements in the business cycle. Afanasieff et al. (2002); and Naceur, Steiner and Goaied (2003), studies on emerging countries (Brazil, Colombia, Malaysia and Tunisia) documented significant effects of financial liberalization on bank performance.

Afanasieff et al. (2002) also made use of panel data techniques to uncover the main determinants of bank performance in Brazil and found out that macroeconomic variables such as GDP growth rate, inflation expectations are important in determining bank profitability over time. Neeley and Wheelock (1997) also explored the profitability of sampled US commercial banks and found a positive impact of per-capita income on profitability.

Overall, empirical review for this research provides back ground information of commercial bank profitability in general drawing from various studies which are largely focused on developed countries, a few in developing countries and limitedly on Africa. Information on African banking systems seems to be scanty and limiting in terms of scope and extent of econometric methods to explain bank profitability determinants. In light of these knowledge gaps and methodological requirements, the paper provides additional empirical evidence using a larger scope of sample commercial banks drawn from 42 SSA countries and applying robust econometric panel methods to quantify the relations ship bank profitability and determinants.

\section{Conceptual Framework and Methodology}

\subsection{Conceptual Framework}

In this section, the theoretical basis for generating bank profitability function is explained. The basis for the variable identification that was considered in the model specification is also illustrated. Adopting the theoretical 
model with some extensions generated a generalised model that was used to estimate the determinants of commercial bank profitability in Sub-Saharan Africa (SSA) using a panel data set drawn from 42 countries.

\subsection{Theoretical Framework for Commercial Bank Profitability Measurement}

\subsubsection{Theoretical Basis for the Model}

A cost efficiency profit model was employed to measure bank profitability. This approach was adopted from the work done by Joaquin Maudos et al. (1999); Mercia, et al. (2002); Marco (2006), Goddard, et al. (2004); and Panayiotis et al. (2005), among others on bank efficiency in developed and a few developing economies. In measuring bank profitability using this framework, bank as well as macroeconomic indicators are utilised as inputs and outputs in the estimation process.

\subsubsection{Cost Efficiency Model}

The cost efficiency frontier is a technical efficiency concept based on a production function that is used to measure bank cost efficiency. Cost efficiency is derived from the cost function and is a modified form of Cobb-Douglas production function. This provides information on how close (or far) bank costs are from the best practice, producing the same output under similar conditions.

Cost and profit efficiency definitions correspond, respectively to two important economic objectives: cost minimisation and profit maximisation. Cost efficiency is the ratio between the minimum cost at which it is possible to attain a given volume of production and the cost actually incurred. Thus, efficiency volume (Ec) implies that it would be possible tom produce the same vector of production (1- Ec).100 percent of costs. Efficiency ranges between $(0,1)$ interval, and equals one for the best-practice bank in the sample.

The costs of the bank depend on the output vector (y), the price of inputs (w), the level of cost inefficiency (u) and a set of random factors $(v)$ which incorporate the effect of errors in the measurement of variables. Thus the cost function is simply expressed as:

$$
C=C(y, w, u v)
$$

In logarithmic terms, assuming that the efficiency and random error terms are multiplicatively separable from the remaining arguments of the cost function;

$$
\ln C i=f(y i, w i, \beta)+\ln v i+\ln u i
$$

Where $\mathrm{Ci}$ is the observed cost of production; $\mathrm{yi}$ is the logarithm of output quantity of bank variables; wi is the vector of logarithms of input prices, $\beta$ is a vector of unknown parameters to be established; vi is the random error term and ui is the non-negative inefficiency effect.

The profit efficiency function is generated by adopting the reduced form of the cost efficiency generalised equation (2), by replacing the cost variable with a profit variable as;

$$
\Pi i t=x i t \beta+v i t-\text { uit }
$$

where $\Pi$ is the profit variable and $X i=$ other bank variable indicators vit are random errors assumed to be independently normally distributed, uit is group specific variation that is time invariant.

The model permits estimations of unbalanced panels and uis are assumed to be exponential function of time, involving only one unknown parameter. Estimating bank profitability, this study also adopts a similar framework as applied by Naceur et.al. (2003) on Tunisian banks and Panayiotis et al. (2005) on Greece banks.

Based on economic theory, the general functional form of profit efficiency is expressed as;

$$
\Pi i t=\alpha+\alpha i \sum \Pi t-i+\beta i X i t+\gamma M a c r o+u i t
$$

where $\Pi i$ is the profitability variable and $\mathrm{Xi}=$ other bank variable indicators, and Macro are macroeconomic variables. Empirical theory identifies average asset ROAA, net interest margin NIM and return on average equity $R O A E$ as common possible choices for measuring bank profitability. Macro refers to macroeconomic factors which influence bank behavior.

\subsubsection{Model Specification and Variables}

Model specification and variable identification is implemented in line with Naceur et al. (2003) and Panayiotis et al. (2005) classification of bank indicators. Bank indicators are classified into six categories: profitability that measures the overall performance of the bank; capital adequacy that measures the bank ability to meet regulated capital standards; credit risk that measures changes in the bank loan quality and risk; operational efficiency that measures the bank ability to generate revenue, pay, expenses and measure of employment expense; liquidity ratio that measures the changes in the bank cash position; and growth indicator that measures the bank change in 
assets. It is on the basis of this classification that the regression analysis of estimating bank profitability is implemented.

Using the profitability function equation and considering actual variable notations, the specification is given by;

$$
\Pi i t=c+\beta 1 \ln T A i t+\beta 2 \text { ETAit }+\beta 3 \ln T D i t+\beta 4 \text { CTIRit }+\beta 5 N L T A i t+\beta 6 \ln \text { GDPAit }+\beta 7 I N F L i t+\varepsilon i t
$$

where Iit is profitability variable represented by either return to average assets $R O A A$ or net interest margin NIM or return on average equity ROAE, LnTA is growth in bank assets, ETA is bank equity to total assets, $\ln T D$ growth in bank deposits, CTIR is cost to income ratio, liquidity ratio NLTA is net loans to total assets, $\ln G D P A$, is $G D P$-growth and $I N F L$ is inflation expectation given by current inflation.

\subsubsection{Variables and Expected Impact on Bank Profitability}

Table 1 presents the variables and expected impact on bank profitability as concluded in empirical studies by Anthanasoglou et al. (2005), among others on studies on bank performance largely in I $\mathrm{n}$ developed economies and limitedly on Africa.

Table 1. Determinants of banks' profitability and expected impact

\begin{tabular}{cc}
\hline Explanatory variable & Expected impact \\
\hline Growth in total assets - $($ lngta $)$ & Positive \\
Capital adequacy - (eta) & Positive \\
Growth in total deposit- $($ lnt $)$ & Positive \\
Cost income ratio - $($ ctir $)$ & negative \\
Liquidity ratio - $($ llta) & negative \\
Growth in GDP- (lngdpa) & Positive \\
Inflation - (infl) & Negative \\
\hline
\end{tabular}

Source: Empirical literature.

\subsection{Methodology, Empirical Data and Analysis}

To construct the sample, data is drawn from financial statements of individual banks provided in the Bank-Scope-Database. The Bank-Scope Database is a collection of data of balance sheets, income statements and other relevant financial accounts of several banks in the World. The data base is accessed through Bank of Uganda (BoU). To ensure consistency, only data for commercial banks in the unconsolidated format is used. The period of study is 1999 to 2006 . Data is generated from 42 countries and 216 commercial banks with at least two years of operation from 1999 to 2006. In total, there are 1316 observations. The specification takes a static framework as there was no verified time trend effect in the specification. Both Bank levels as well as macroeconomic variables that influence bank profitability are included in line with theory and empirical evidence. Bank level variables are bank asset growth in assets, capital adequacy, credit risk, operating efficiency, liquidity ratio; while macroeconomic variables include growth in GDP and inflation. Data is downloaded in Microsoft Office, arranged in panel sets, and analyzed using STATA- 11. The same data set, but using different variables is used in estimating the model.

In order to understand the variability in bank profitability across SSA sub-region, the banks are further categorized by income category based GDP-per-capita. Category one are commercial banks drawn from low income country of GDP per-capita of less or equal to 750 USD and second category are commercial banks drawn from medium income countries of GDP per-capita of greater or equal 750 USD. By disaggregation the first category is 164 group banks and second category is 62 group banks. The bank categories are labeled gdpcdummy for lower and gdpcdummy 2 for medium income category respectively.

Estimation utilizes panel methods of fixed effects (FE), random effects (RE) and feasible generalized Least Squares (FGLS) in static framework. In estimating the model, bank profitability is a dependent variable and represented by return on average assets (ROAA), net interest margin (NIM) and return on average equity (ROAE), but the discussion used the ROAA regression results.

\subsubsection{Criteria in Commercial Bank Selection}

Using the Bank Scope data base, bank data was downloaded in Microsoft Excel 2007. The final selection of the bank to part of $r$ the sample was based on a banking data for a minimum period of two years within the timeframe from 1999 to 2006. Ownership of these banks was not specified. They were selected as commercial 
banks.

\subsection{Robustness and Specification Tests}

Panel stationary test is conducted by the Augmented Dickey-Fuller (DF) and Fisher type-tests that are recommended for unbalanced panels (Baltagi, 2005). In this test non-stationarity in the panel series is the rejection of null hypothesis that all the panels have unit root. This is where the $t(z)$-statistic is less than $t$ (z)-critical. The fisher-test uses four other type tests including inverse-chi-squared test (P), inverse normal (Z), inverse logit $\left(\mathrm{L}^{*}\right)$ and modified inv.chi-squared $(\mathrm{PM})$. The inference is made using at a maximum limit of $\mathrm{p}$ value $=1.00$. Baltagi (1998) concluded that when panels are stationary, it so happens that they are integrated and could generate at least one co-integrating equation.

\section{Determinantrs of Bank Profitability in Sub-Saharan Africa}

\subsection{Data Characteristics}

Table 2 presents the descriptive statistics of the variables utilized in this study. The variables are computed in percentage points and millions of US dollars at constant 2000 prices in USD. The results confirm the adequacy of the data used in estimating the commercial bank profitability, ranging above 1000 observations. Looking at profitability as a key measure of bank performance, a mean of 2.28 percent, minimum and maximum of minus 56.7 percent to 49.64 percent would indicate that most of the SSA commercial banks have lower levels of profitability which could be arising from the low levels of capitalization, low levels of liquidity, high operational inefficiency, low levels of demand deposits, low levels of growth in assets and poor macroeconomic environment characterized by low growth in GDP and high inflation pressures.

Table 2. Descriptive statistics of the variables

\begin{tabular}{cccccc}
\hline Variable & Obs. & Mean & Std.dev. & Min & Max \\
\hline Return on average asset (roaa) & 1297 & 2.28 & 4.31 & -56.7 & 49.64 \\
Growth in banks assets(lta) & 1285 & 5.73 & 2.71 & 0.072 & 762805 \\
Growth in bank deposits $($ ltd $)$ & 1261 & 5.51 & 2.81 & 0.194 & 5874527 \\
Operational efficiency(ctir) & 1207 & 62.98 & 44 & 1.66 & 974 \\
Capital adequacy (eta) & 1294 & 13.18 & 9.9 & 1.6 & 80.27 \\
Liquidity- (nlta) & 1315 & 43.93 & 19.78 & 0.21 & 96.64 \\
Growth in GDP (lgpda) & 1138 & 22.36 & 1.2 & 19.81 & 25.8 \\
Inflation rate (infl.) & 1091 & 13.87 & 41.57 & -10 & 550 \\
\hline
\end{tabular}

Source: Panel estimates: 1999 - 2006.

In Annex II, the correlation relationship between the explanatory variables for measuring commercial bank profitability is illustrated. The results confirm some level of correlation between the dependent variable (return on average asset) and independent variables (bank assets, bank deposits, operational efficiency, capital adequacy, GDP and inflation). However, the overall correlation relationships between the explanatory variables range below 0.5 , implying a lower degree of collinearity between the variables.

\subsection{Robustness and Specification Test}

\subsubsection{Panel Unit-Root and Co-Integration Test}

To test for stationarity of the variables in the model, unit-root test by the Augmented Dickey-Fuller and Fisher-type tests was applied. This test is recommended by Baltagi (1998 and 2005) and in other econometric literature, as appropriate for unbalanced panels for an advantage of accommodating any number of lags. The fisher test uses four types of other tests: inverse-chi-squared (P), inverse normal $(\mathrm{Z})$ inverse logit $\left(\mathrm{L}^{*}\right)$. Table 4.2 shows the results of the Fisher-test for stationarity. The tests were implemented in levels (zero differenced and lag length (2). 
Table 3. Unbalance panel unit-root test results

\begin{tabular}{|c|c|c|c|c|c|c|}
\hline \multirow{3}{*}{ Variable } & \multicolumn{6}{|c|}{ Fisher-type panel tests } \\
\hline & \multicolumn{2}{|c|}{$\mathbf{P}$} & \multicolumn{2}{|c|}{ PM } & \multirow[t]{2}{*}{ Lag length } & \multirow{2}{*}{$\begin{array}{c}\text { Deduction } \\
P \leq \alpha ; p \geq \alpha\end{array}$} \\
\hline & Statistic & P.Value & Statistic & P.Value & & \\
\hline Bank profitability -(roaa) & 0.000 & 1.000 & -12.000 & 1.000 & 2 & $\mathrm{I}(0)$ \\
\hline Growth in bank asset-(lta) & 0.000 & 1.000 & -12.1244 & 1.000 & 2 & $\mathrm{I}(0)$ \\
\hline Bank capitalization ratio- (eta) & 0.000 & 1.000 & -12.1655 & 1.000 & 2 & $\mathrm{I}(0)$ \\
\hline Growth in bank deposits (ltd) & 0.000 & 1.000 & -12.083 & 1.000 & 2 & $\mathrm{I}(0)$ \\
\hline Operational efficiency- (ctir) & 0.000 & 1.000 & -11.5758 & 1.000 & 2 & $\mathrm{I}(0)$ \\
\hline Growth in GDP $(\operatorname{lng} d p a)$ & 0.000 & 1.000 & -11.8322 & 1.000 & 2 & $\mathrm{I}(0)$ \\
\hline Growth in real exchange rate-(lexe) & 0.000 & 1.000 & -11.5326 & 1.000 & 2 & $\mathrm{I}(0)$ \\
\hline
\end{tabular}

Notes:Ho: All the panels contain unit roots, HA: At least one panel is stationary, Panel mean included, Time trend included, Drift term excluded. Source: Panel Computation, 1999 - 2006.

The t-statistic of less or equal to p-value shows a rejection of the null hypothesis that at least one panel has non-stationary variables. The findings show that all the variables are stationary at zero difference level and lag length (2) for the both P and PM-fisher type tests. When panel variables are stationary, they as well integrated and could at least generate one co-integrating relationship (Baltagi, et al, 2005).

When panel variables have no unit root, they are stationary and therefore integrated. Econometric literature shows that when variables are integrated, they generate at least one co-integrating equation for efficiency analysis. This is confirmed by a rejection of the null hypotheses of stationarity. The results prove that the key bank variables: growth in bank assets, capital adequacy, credit risk, operational efficiency and bank liquidity; as well as the macro economic variables; of growth in GDP and inflation expectation were efficient and appropriate in measuring bank profitability in SSA over the study period 1999 to 2006.

\subsubsection{Hausman Specification Test}

This tests the efficiency and consistency between the FE and RE estimators. Although the econometric theory recommends RE estimation for unbalanced panels, a confirmatory test by use of the Hausman specification test is usually carried out to evaluate the efficiency between FE and RE estimation methods. A rejection of the null hypothesis is when Prob $>$ chi2 $=\alpha$, confirmed the efficiency and consistency of the $\mathrm{RE}$ in estimating the model. Table 4.3 presents the results based on the test.

Table 4. Hausman specification test between FE and RE estimators

\begin{tabular}{ccccc}
\hline Variable & \multicolumn{3}{c}{ Coefficients } \\
(b-B) Difference & Sqrt)diag $\left(V \_b-V \_B\right)$ \\
\hline Growth in bank assets- (lnta) & -0.3952 & -0.4792 & 0.7890 & 0.3621 \\
Bank capitalization- (eta) & 0.2076 & 0.1188 & 0.8883 & 0.0220 \\
Growth in bank deposits - lntd) & 1.4975 & 0.6201 & 0.8755 & 0.3775 \\
Liquidity ratio - (nlta) & -0.0269 & -0.0432 & 0.0163 & 0.0128 \\
Operational efficiency - (ctir) & -0.0335 & -0.4041 & 0.0069 & 0.0032 \\
GDP growth- (lngdpa) & -2.5560 & -0.3872 & -2.1684 & 1.0992 \\
Growth in exchange rate- (lnexe) & -0.0033 & 0.0070 & 0.0036 & 0.0030 \\
\hline
\end{tabular}

Notes: $1 . \mathrm{b}=$ consistent under Ho and HA; obtained from xtreg.

2. $\mathrm{B}=$ inconsistent under HA, efficient under Ho; obtained from xtreg.

3. Test: HO: difference in coefficient is systematic.

4. Chi2 $\left.(7)=(b-B)^{\prime}\left[V_{-} b-V \_B\right)(-1)\right](b-V)=56.61 ;$ Prob $>$ chi2 $=0.0000$.

Source: Panel Computation, 1999 - 2006.

The findings are consistent with theory that the random effects estimator is expected to generate more efficient results where there is a high variability in the data set. Efficiency is achieved in controlling for a possible endogeinty and auto-correlation effects associated with dynamic lag models (Arrellano and Bover (1995) and Blundell and Bond (2000). The evaluation also confirmed that there was no time effect in the regression results hence focusing the analysis on static specification as shown in Annex V. 


\subsection{Discussion of Results}

Table 5 shows the regression results for all the sampled banks. Estimation is by applying the random effects (RE) technique. Econometrics recommends the random effects (RE) method as an efficient estimator for unbalanced panel models (Baltagi, 1999). This is confirmed by the Hausman specification test which evaluates the efficiency between the random effects (RE) and fixed effects (FE) estimators for the panel regressions.

This is consistent with theory that random effects estimator is expected to generate more efficient results after controlling for possible endogeinty and autocorrelation effects associated fixed effects models (Arrellano and Bover, 1995) and Blundell and Bond (2000). The efficiency of the RE results was confirmed by FGLS results which generated the similar results.

Table 5. Random effects regression results for all sample banks

\begin{tabular}{|c|c|c|c|c|c|c|}
\hline \multirow{2}{*}{$\begin{array}{c}\text { Variable } \\
\begin{array}{c}\text { Dependent variable }=\text { Bank } \\
\text { profitability }-(\text { roaa })\end{array}\end{array}$} & \multicolumn{2}{|c|}{ FE Model } & \multicolumn{2}{|c|}{ RE Model } & \multicolumn{2}{|c|}{ FGLS Model } \\
\hline & Coeff. & P.Value & Coeff. & P.Value & Coeff. & P.Value \\
\hline Growth in banks assets- (lnta) & -0.034 & 0.378 & -0.667 & $0.076^{*}$ & -0.4666 & $0.075^{*}$ \\
\hline Bank capitalization ratio - (eta) & 0.2077 & $0.000^{* * *}$ & 0.1146 & $0.088^{*}$ & 0.1146 & $0.000^{* * *}$ \\
\hline Growth in bank deposit - (lntd) & 1.4975 & $0.001^{*}$ & 0.6195 & $0.018^{* * *}$ & 0.6196 & $0.018^{* * *}$ \\
\hline Bank liquidity- (nlta) & -0.02692 & $0.060^{*}$ & -0.0419 & $0.000^{* * *}$ & 0.0419 & $0.000^{* * *}$ \\
\hline Operational efficiency - (ctir) & -0.0335 & $0.000^{* *}$ & -0.0404 & $0.000^{* * *}$ & 0.0404 & $0.000^{* * *}$ \\
\hline Growth in GDP - (lngdpa) & -2.5556 & 0.021 & -0.3872 & $0.000^{* * *}$ & -0.3872 & $0.000^{* * *}$ \\
\hline Inflation- (inf) & -0.0033 & -0.117 & -0.006 & $0.063^{*}$ & -0.006 & $0.062^{*}$ \\
\hline Constant & -2.1973 & 0.118 & 13.3571 & $0.000^{* * *}$ & 13.3571 & $0.000^{* * *}$ \\
\hline No. of Obs. & 967 & & 967 & & 967 & \\
\hline Group Banks & 184 & & 184 & & 184 & \\
\hline R.sq: & 0.14 & & 0.27 & & & \\
\hline F-Statistics- $F(7,776)=32.86$ & $F>0.00$ & & & & & \\
\hline Wald-Statistics & & & Prob $>$ chi2 & & & \\
\hline -Wald $\operatorname{chi} 2(7)=359.60$ & & & $=0.000$ & & & \\
\hline Wald-Statistics & & & & & Prob $>$ chi 2 & \\
\hline- Wald $\operatorname{chi} 2(7)=362.60$ & & & & & $=0.00$ & \\
\hline Log likelihood & & & & & -4974.537 & \\
\hline
\end{tabular}

Source: Panel estimation, 1999-2006.

Note: $1 .(\operatorname{Ln})=$ natural $\operatorname{logs}(\log ) ; 2 .\left({ }^{* * *} ;{ }^{* *} ;{ }^{*}\right)=$ Significant at $0.01,0.05$ and 0.10 , respectively.

Using return to average asset (ROAA) as measure of bank profitability, the findings reveal that the RE and FGLs have consistent and efficient results. The Wald statistic confirms that the model used as well as the variables are significant and correctly specified. Detailed discussed of the results follows.

The coefficient of the variable representing growth in bank assets is negative and significant at 10 percent significance level. A negative relationship of bank size suggests that the smaller the bank the, the more efficient the bank will be. Thus the case of Sub-Saharan commercial banks does not support the economies of scales the argument that the larger the bank, the bank will be more efficient. As observed by Hiroyuki (2009), among others, on SSA commercial banks, negative coefficient supports diseconomies of scale argument on bank on the relationship between growth in bank size and profitability.

The coefficient of the variable representing bank risk (growth in bank deposits) is positive and significant at 1 percent, 5 percent and 10 percent levels. This is consistent with Naceur et.al. (2003) finding that, other things constant, more deposits are transformed into loans. The higher the interest rate margins, the higher the profits and banks are able to shield themselves against hazards of credit risk resulting from adverse selection and moral hazard.

The coefficient of the variable representing capital adequacy (equity to total assets) is positive and significant with expected signs at1 percent, 5 percent and 10 percent levels, respectively. This would imply that well capitalized banks experience higher returns and the finding is consistent with Anthanasoglou et. al.(2006). Berger et.al. (1995), further showed that relaxation of one period assumption allows an increase in earnings to raise capital, provided the earnings are not fully distributed as dividends. Relaxation of perfect capital markets could allow capital to raise expected earnings by reducing the expected costs of bankruptcy financial distress in general. Positive effect on bank profitability could arise from relative growth in bank profitability as result of 
the financial sector reforms (IMF, 2007). The positive impact of the variable to bank profitability in most SSA countries reveals some levels of increased capitalization of the banks following the recent reforms in the financial sectors. This variable also measures the bank ability to withstand losses.

The coefficient of the variable representing liquidity risk (net loans to total assets) is negative and significant with expected signs at 1 percent, 5 percent and 10 percent levels, respectively. This is consistent with theory that the higher liquidity ratio could influence bank profitability. Higher ratios may be an indicative of improved bank profitability because of increased interest incomes from borrowed funds (Berger et al., 2006). On the other hand, the same study pointed out that this variable could also have a negative effect on bank profitability. However theory has is that this variable can have a negative effect on bank profitability. This is when high ratios could result in reduced liquidity due increase in loan defaults

The coefficient of the variable representing operational efficiency (cost/income) is negative and significant with expected signs. This is consistent with theory that the higher costs of operation negatively affect bank profitability. Operational efficiency indicator is the expense variable and explains how banks could be efficient in resource allocation and utilization including human resource and technological improvements in banking. The negative growth in bank profitability could probably be explained by high costs of operation across commercial banks.

The macroeconomic variables chosen for this study are growth rate in GDP and inflation. The coefficient of growth in GDP variable, measured at constant 2000 prices in US dollars, is negative and significant at 1, 5 and 10 percent levels. This finding agrees with theory and empirical evidence that; the relationship between GDP trend growth and bank profitability could be pro-cyclical. There are several reasons why the effect of growth in GDP to bank profitability could be negative or positive ((Naceur et.al., 2003 and Panayiotis et al., 2005). Firstly, bank credit could decrease during economic down swings, since such periods are normally associated with increased risk and vice-versa. In absence of this variable however; it is also observed that this variable could be partly captured by bank-specific variables.

For inflation variable, the coefficient is negative and significant with expected signs according to theory. This is consistent with the finding by Panayiotis et al.(2005) on Greek banks that that the effect of inflation on bank profitability depends on the ability of inflation forecast by the bank management. If predictions become correct, such adjustments in interest rates could be incorporated inflation expectation, to achieve higher profits. Economic theory also argues that if the bank managers are able to predict inflation and incorporate in their cost structure the effect could be positive.

To check the consistency of the result by country income category, disaggregated regression is implemented including the dummies for lower and medium income category commercial banks. The results are consistent and efficient for the lower income category commercial banks with the results for the total sample signifying that the majority of the banks are from the lower income category of up to GDP per-capita of 750 US dollars as illustrated in annex III.

\section{Conclusion and Policy Implications}

\subsection{Conclusions}

The research is conducted to investigate the impact of bank level and macroeconomic factors on the profitability of commercial banks in Sub-Saharan Africa. Limiting empirical studies explain commercial bank performance in SSA motivated this study. The study utilizes unbalanced bank panel data of 216 group banks drawn from 42 countries spanning the period 1999 to 2006. The random effects panel methods are employed to estimate bank profitability. The findings call for a number of policy measures for improved competitiveness of SSA commercial banks in the financial intermediation services to the public. The findings show that.

The bank level variables such as capital adequacy, growth in bank deposits, have positive influence on bank profitability. Positive growth of in these indicators could be a result of banking sector liberalization that has been implemented in most of SSA countries since 1980s and 1990s. As result banks have been opened to foreign competition and ensured sustained capital and fund inflows to recapitalise the banks and increase their liquidity positions to supply private sector credit.

On the hand other hand, growth in bank assets, operational efficiency and bank liquidity indicators have negative effect on bank profitability. The negative effect of these indicators could be explained by disproportionate accumulation of assets through mergers and acquisitions of foreign based banks at high costs that has occurred in SSA in the last two decades (IMF, 2007). On the other hand, the negative effect of bank liquidity can be explained by low bank lending as banks hold more money than statutory required for precautionary purposes. 
Because of high risk perceptions of private sector credit, SSA commercial banks tend to invest in risk free bearing assets such as treasury bills and bonds, with little attention to private sector lending. This could have a crowding out effect to private investment through high interest rates and a negative effect to long term economic growth.

For macro-economic variables, the findings show that both growth in GDP and inflation had a negative effect on bank profitability. Negative effect could imply very low and negative economic growth experienced by most of the Sub-Saharan countries over the study period and as is consistent with theory (Naceur et.al. 2003 and Panayiotis et al., 2005). The negative effect of inflation to bank profitability reflects the inability of bank managers to forecast inflation in their cost structure to realize profits (Panayiotis et al., 2005). As result the interest rate charged are lower than actual inflation, resulting into losses.

The key conclusions drawn from this study therefore are that: i) that the key bank variables such as capital adequacy, bank liquidity, asset quality, operational efficiency, growth in bank deposits; and ii) macroeconomic variables of growth in GDP and inflation have significant influence on bank profitability in Sub- Saharan Africa.

\subsection{Policy Implications for Study}

Profitability for SSA banks can only be achieved if bank managers and policy makers continue to pay particular attention to bank-specific as well macroeconomic factors that have influence on their profitability. Given the lower profitability indicator average at about 11 percent across all commercial banks over the study period, it would be important to implement second generation reforms of the banking sector to bring about the desired growth performance of the industry. These findings call for a number of policy interventions in SSA commercial banking industry for improved performance in profitability and factor productivity growth which are among the key measures of bank performance in the sub-region.

For bank profitability determinants, the study points out to the need for bank managers to gear towards optimum utilization of resources, observe prudent risk management procedures for sound and competitive services for better returns. There is also need for commercial banks in SSA to be responsive to risks associated with changing macroeconomic factors in a liberalised environment.

Results confirm the importance of bank level as well as macroeconomic factors to the bank profitability. This would suggest that banks should ensure efficient and effective supervisory and related service for optimum utilization of resources. This would include equitable investment of resource gains from different investments such as earning bonds and securities, prudent resource management to avoid high levels of liquidity risk, increased supervision to avoid high levels of non-performing loan ratios, ensure sound competitive environment and excellence in services to maintain competitive banking. Further, for improved profitability, bank managers should also endeavor to look for options that increase the levels of bank capitalization, employ innovative ways of reducing the proportion of non-interest bearing assets as well as investing resources in stock and capital markers which are less risk free ventures to bank business. At national level, there is need for governments to employ efficient regulatory frameworks that reduce concentration and spur competition and boost the development of equity markets to improve bank profitability as and stock market is found to be complementary in financial intermediation.

On the macro economic effects to bank profitability, there is also need for bank managers to be responsive to risks associated with changing macroeconomic factors such as GDP growth and inflation, among others. This would suggest that policies aimed at stabilizing inflation and GDP growth should be given priority in fostering financial intermediation. Since the output cycle matters for bank performance, fiscal and monetary policies that are designed to promote output stability and sustainable growth are good for financial intermediation.

This research is a springboard for policy improvement in the diverse financial sectors in SSA. The governments and other concerned financial management institutions need to take into account the main fabrics and other policy repercussions towards commercial bank profitability that have gained considerable importance in SSA financial sector. This could probably be achieved through undertaking comprehensive and rigorous stress testing to avoid risks associated with market failures in the sector.

In the final analysis, this study opens up areas for further research. One would be to investigate on how SSA commercial bank profitability, compares with other regions and continents. Two would be to explore other bank profitability measures and how they are they explain bank performance; to add on the existing literature for improving the sector. Three would be to explore other appropriate econometric methods that improve the understanding bank profitability for effective for effective policy decision making in dynamic banking sector 
across the continent.

\section{References}

Afanasieff, T., Lhacer, M., \& Nankane, M. (2002). The determinants of bank interest spreads in Brazil. Banco Central di Brazil Working Papers.

Al-Hashimi, A. (2007). Determinants of bank spreads in Sub-Saharan Africa. IMF DraftWorking Paper, 05/06.

Altunbas, Y., Carbo, S., Gardener, E. P. M., \& Molyneux, P. (2007). Examining the relationships between capital, risk and efficiency in European banking. European Financial Management, 13(1), 49-70. http://dx.doi.org/10.1111/j.1468-036X.2006.00285.x

Anthanasoglou, P., Delis, M., \& Staikouras, C. (2006). Determinants of banking profitability in South Eastern European region. Bank of Greece Working Paper, 06/07.

Arellano, M., \& Bover, O. (1995). Another look at instrumental variable estimation of error models. Journal of Econometrics, 68, 29-51. http://dx.doi.org/10.1016/0304-4076(94)01642-D

Baltagi, B. H. (1998). Within two way equivalent to two within one way problem. Econometric Theory, 13, 759.

Baltagi, B. H. (2005). Econometric analysis of panel data (3rd ed.). John Wiley and Sons,Ltd.

Berger, A. N. (1995). The profit-structure relationship in banking: Test of market-power and efficient structure hypotheses. Journal of Money, Credit and Banking, 27, 404-431. http://dx.doi.org/10.2307/2077876

Berger, A. N., \& Humphrey, D. B. (1997). Efficiency of financial institutions: International survey and directions for future research. European Journal of Operational Research, 98, 175-212. http://dx.doi.org/10.1016/S0377-2217(96)00342-6

Berger, A. N., \& Mester, L. J. (1997). Inside the black box: What explains differences in the efficiencies in financial institutions? Journal of Banking and Finance, 21, 895-947. http://dx.doi.org/10.1016/S0378-4266(97)00010-1

Bikker, J. (2001). Efficiency in the European banking industry: An exploratory analysis to rank countries cashiers. Economiques de Bruxelles, 172, 3-28.

Bikker, J., \& Hu, H. (2002). Cyclical patterns in profits, provisioning and lending of banks and procyclicality of the new basel capital requirements. BNL Quarterly Review, 221, 143-175.

Blundell, R., \& Bond, S. (2000). Initial conditions and moment restrictions in dynamic panels data model. Journal of Econometrics, 87, 115-143. http://dx.doi.org/10.1016/S0304-4076(98)00009-8

Bourke, P. (1989). Concentration and other determinants of bank profitability in Europe, North America and Australia. Journal of Banking and Finance, 13, 65-79. http://dx.doi.org/10.1016/0378-4266(89)90020-4

Boyd, J. H., \& Runkle, D. E. (1993). Size and performance of banking firms. Testing the predictions of theory. Journal of Monetary Economics, 31, 47-67. http://dx.doi.org/10.1016/0304-3932(93)90016-9

Brock, P., \& Rojas, S. L. (2000). Understanding the behavior of bank spreads in Latin America. Journal of Development Economics, 63, 13-134. http://dx.doi.org/10.1016/S0304-3878(00)00102-4

Chirwa, E., \& Mlachila, M. (2004). Financial reforms and interest rate spreads in the commercial banking system in malawi. IMF Staff Papers, 51(1), 96-122.

Claessens, S., Demirguc-Kunt, A., \& Huizinga, H. (2001). How does foreign entry effects of domestic banking markets? Journal of Banking and Finance, 25, 891-911. http://dx.doi.org/10.1016/S0378-4266(00)00102-3

Das, A., Nag, A., \& Lay, S. (2004). Liberalization, ownership and efficiency in Indian banking: Anon-Parametric approach. Department of Economics Working Paper Series.

Demerguc-Kunt, A., \& Huizinga, H. (1999). Determinants of commercial bank interest margins and profitability: Some international evidence. World Bank Economic Review, 13, 379-400. http://dx.doi.org/10.1093/wber/13.2.379

Demerguc-Kunt, A., \& Huizinga, H. (2001). Financial structure and bank profitability in financial structure and economic growth: A cross-country comparison of banks, markets and development. In Asli Dermirgue-Kunt, \& Rose, L. (Eds). Cambridge, MA: MIT Press.

Eichengreen, B., \& Gibson, H. D. (2001). Greek banking at the draw of the New Milleniium. CEPR Discussion Paper 2791, London. 
Goddard, J., Molyneux, P., \& Wilson, J. O. S. (2004). The profitability of European banks: Cross sectional and $\begin{array}{lllll}\text { dynamic panel } & \text { analysis. }\end{array}$ http://dx.doi.org/10.1111/j.1467-9957.2004.00397.x

Hauner, D., \& Peiris, S. S. (2005). Bank efficiency and competition in low-income countries. The case for Uganda. IMF Working Paper, WP/05/240.

Hiroyuki, K. (2009). Efficiency of commercial banks in Sub-Saharan Africa: A comparative analysis of domestic and foreign banks. Asian Development Bank Institutute, Totyo, Japan.

Leightner, J. E., \& Lovell, C. A. K. (1998). The impact of financial liberalization on the performance of Thai banks. Journal of Money, Credit and Banking, 33, 719-766.

Lovell, C. A. K. (1996) Deregulation and productivity decline: The case of spanish savings banks. European Economic Review, 40(6), 1281-1303. http://dx.doi.org/10.1016/0014-2921(95)00024-0

Marco, K., \& Peter, Z. (2006). Bank consolidation and bank efficiency in Europe. University of Ljubjana, Faculty of Economics, Ljubljana, Slovenia.

Mathieson, D. J., \& Roldos, J. (2001). Foreign banks in emerging markets. In Litan, R. E., Masson, P., \& Pomerleano, M. (Eds.), Open doors-foreign participation in financial systems in developing countries (pp. 15-55). Washington DC: Brookings Institution Press.

Maudos, J., Pastor, J., Perez, F., \& Quesada, J. (2002). Cost and profit efficiency in European banks. Journal of Financial Markets, Institutions and Money, 12(1), 33-58. http://dx.doi.org/10.1016/S1042-4431(01)00051-8

Mercia, M. C., Evren, O., \& Hassan, T. (2002). Bank performance around the introduction of subsidiary banks in the US. Journal of Banking and Finance, 17, 389-40.

Molyneux, P., \& Thornton, J. (1992). The determinants of European bank profitability. Journal of Banking and Finance, 16, 1173-1178. http://dx.doi.org/10.1016/0378-4266(92)90065-8

Mugume, A. (2006). Competitition among financial institutions in Uganda and economic growth. EARC meeting, Kampala Uganda.

Naceur, A. B., Steiner, R., \& Goaied, M. (2003). The determinants of the Tunisian banking industry profitability: Panel evidence. ERF Research Fellow.

Neely, P. A., \& Wheelock, D. C. (1997). Why banks performance vary across states? Review-Federal Reserve Bank of St. Louis, 27-38.

Panayiotis, P., Anthanasoglou, S., Brissimis, N., \& Mathaios, D. D. (2005). Bank specific, industry-specific and macroeconomic determinants of bank profitability. Bank of Greece Working Paper, 25.

Pasiouras, F., \& Kosmidou, K. (2007). Factors influencing the profitability of domestic and foreign commercial banks in European Union. Journal of International Business and Finance, 21, 222-237. http://dx.doi.org/10.1016/j.ribaf.2006.03.007

Roland, K. P. (1997). Profit persistence in larger US bank holdind companies: An empirical investigation. Office of the Controller Currency Economic Working Paper, 2-97.

Schure, P., Wagenvoort, R., \& O'Brien, D. (2004). The efficiency and conduct of European banks: Developments after 1992. Review of Financial Economics, 13(2), 371-96. http://dx.doi.org/10.1016/j.rfe.2004.01.001

Short, T. (1979). Monitoring the macroeconomic determinants of banking system stability. Journal of Banking and Finance, 17(2), 117-137.

Toddard, J., Molyneux, P., \& Wilson, J. O. S. (2004). Dynamics of growth and profitability in banking. Journal of Money, Credit, and Banking, 36(6).

Weaver, S. C. (2001). Measures of economic value added. A survey of the practices of EVA proponents. Journal of Applied Finance, 11, 50-60.

World Bank (WB). (2006). Global monitoring report 2005. Millennium Development Goals:From Consensus to Momentum (Washington).

Yigremachew, B. (2008). Determinants of private banks profitability in Ethiopia: Panel evidence. 


\section{Appendix}

Appendix I. List of countries selected for the study

\begin{tabular}{cccc}
\hline No. & Country & No. & Country \\
\hline 1 & Angola & 22 & Rwanda \\
2 & Benin & 23 & Senegal \\
3 & Botswana & 24 & Tanzania \\
4 & Burkina Faso & 25 & Uganda \\
5 & Burundi & 26 & Zambia \\
6 & Cameroon & 27 & Cape Verde \\
7 & Ghana & 28 & Central African Republic \\
8 & Democratic Republic of Congo & 29 & Chad \\
9 & Ethiopia & 30 & Congo Brazzaville \\
10 & Gabon & 31 & Equatorial Guinea \\
11 & Gambia & 32 & Eritrea \\
12 & Ivory Coast & 33 & Guinea \\
13 & Kenya & 34 & Liberia \\
14 & Lesotho & 35 & Niger \\
15 & Madagascar & 36 & SAO.Tome \\
16 & Mali & 37 & Zimbabwe \\
17 & Mauritania & 38 & Togo \\
18 & Mauritius & 39 & Swaziland \\
19 & Mozambique & 40 & Sierraloen \\
20 & Namibia & 41 & Seychelles \\
21 & Nigeria & 42 & South Africa \\
\hline
\end{tabular}

Appendix II. Correlation matrix for bank profitability model

\begin{tabular}{lcccccccr}
\hline & roaa & ta & e_ta & td & nl_ta & ctir & gdpa & inf \\
\hline Bank profitability & 1 & & & & & & & \\
Total banl assets & 0.0717 & 1 & & & & & & \\
Bank capitalization & 0.1518 & -0.0429 & 1 & & & & & \\
Total bank deposits & 0.0727 & 0.9843 & -0.0449 & 1 & & & \\
Bank liquidity & -0.1255 & -0.0521 & 0.0067 & -0.0534 & 1 & & \\
Operational efficiency & -0.4073 & -0.0423 & 0.1463 & -0.0425 & -0.1469 & 1 & \\
Gdp & -0.06 & -0.0396 & 0.1385 & -0.0382 & -0.011 & 0.0367 & 1 \\
Inflation & -0.0109 & 0.0302 & 0.0316 & 0.0283 & -0.2263 & 0.0255 & -0.0356 & 1 \\
\hline
\end{tabular}


Appendix III. Random effects regression results for low and medium income category banks

\begin{tabular}{|c|c|c|c|c|c|c|}
\hline \multirow{2}{*}{$\begin{array}{c}\text { Variable } \\
\text { Dependent variable }=\text { total } \\
\text { factor profitability }-(\text { roaa })\end{array}$} & \multicolumn{2}{|c|}{ FE Model } & \multicolumn{2}{|c|}{ RE Model } & \multicolumn{2}{|c|}{ FGLS Model } \\
\hline & Coeff. & P.Value & Coeff. & P.Value & Coeff. & P.Value \\
\hline Growth in banks assets- $(\operatorname{lnta})$ & -0.151 & $0.074^{*}$ & -0.1858 & $0.200^{* * *}$ & -2420 & $0.000^{* * *}$ \\
\hline Bank capitalization ratio - (eta) & -86 & $0.000^{* * *}$ & -0.0045 & $0.000^{* * *}$ & -0.0034 & 0.7 \\
\hline Growth in bank deposit - (lntd) & 0.1533 & $0.001^{* * *}$ & 0.1808 & $0.000^{* *}$ & 0.2422 & $0.000^{* *}$ \\
\hline Bank liquidity- (nlta) & 0.0021 & $0.031^{* *}$ & 0.0064 & $0.000^{* * *}$ & 0.0017 & $0.003^{* * *}$ \\
\hline Operational efficiency - (ctir) & 0.0023 & $0.000^{* * *}$ & -0.0422 & $0.000^{* * *}$ & 0.0077 & $0.000^{* * *}$ \\
\hline Growth in GDP - (lngdpa) & -0.1121 & 0.13 & -0.0372 & $0.008^{* * *}$ & -0.0374 & $0.000^{* * *}$ \\
\hline Inflation- (inf) & -0.0024 & 0.431 & -0.0061 & $0.023^{* *}$ & 0.0012 & $0.000^{* * *}$ \\
\hline gdpcdummy & omitted & & -0.083 & $0.000^{* * *}$ & -0.063 & $0.000^{* * *}$ \\
\hline gdpcdummy2 & 0.2411 & $0.007^{* * *}$ & omitted & & omitted & \\
\hline Constant & 1.6451 & $0.011^{* * *}$ & -1.55 & $0.000^{* * *}$ & -1.7215 & $0.000^{* * *}$ \\
\hline No. of Obs. & 953 & & 953 & & 953 & \\
\hline Group Banks & 180 & & 180 & & 180 & \\
\hline R.sq: & 0.28 & & 0.49 & & & \\
\hline F-Statistics- $F(8,765)=70.31$ & $\mathrm{~F}>0.00$ & & & & & \\
\hline Wald-Statistics & & & Prob $>$ chi 2 & & & \\
\hline -Wald $\operatorname{chi} 2(8)=738.25$ & & & $=0.000$ & & & \\
\hline Wald-Statistics & & & & & Prob $>$ chi 2 & \\
\hline -Wald chi2 $(8)=995.68$ & & & & & $=0.00$ & \\
\hline Log likelihood & & & & & -287.8534 & \\
\hline
\end{tabular}

Source: Panel estimation, 1999-2006.

Note: $1 .(\operatorname{Ln})=$ natural $\operatorname{logs}(\log ) ; 2 .\left({ }^{* * *} ;{ }^{* *} ;{ }^{*}\right)=$ Significant at $0.01,0.05$ and 0.10 , respectively; gdpcdummy=low income country category of GDP-per-capita of less or equal to USD 750 and gdpcdummy2=medium income country category of GDP-per-capita of equal or greater than USD 750 .

\section{Copyrights}

Copyright for this article is retained by the author(s), with first publication rights granted to the journal.

This is an open-access article distributed under the terms and conditions of the Creative Commons Attribution license (http://creativecommons.org/licenses/by/3.0/). 